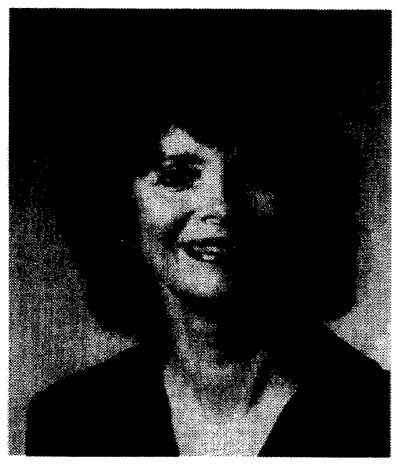

Ruth R. Faden

Ruth R. Faden, M.P.H., Ph.D., is the Philip Franklin Wagley Professor of Biomedical Ethics and Executive Director of The Phoebe R. Berman Bioethics Institute at Johns Hopkins University. She is also a Professor in the Department of Health Policy \& Management in the Johns Hopkins School of Public Health and a Professor of the Department of Medicine in the Johns Hopkins School of Medicine. Additionally, she is a Senior Research Scholar at the Kennedy Institute of Ethics, Georgetown University.

Dr. Faden is the author and editor of numerous books and articles on biomedical ethics and health policy, including A HISTORY AND THEORY OF INFORMED CONSENT (with Tom L. Beauchamp, 1986), AIDS, WOMEN, AND THE NEXT GENERATION (Ruth Faden, Gail Geller \& Madison Powers eds., 1991), HIV, AIDS AND CHIIDBEARING: PUBLIC POLICY, PRIVATELIVES (Ruth Faden \& Nancy Kass eds., 1996).

Dr. Faden is a member of the Institute of Medicine and a Fellow of the Hastings Center and the American Psychological Association. She has served on several national advisory committees and commissions, including the President's Advisory Committee on Human Radiation Experiments, which she chaired. Dr. Faden holds a B.A. from the University of Pennsylvania, a M.A. in General Studies in Humanities from the University of Chicago, and a M.P.H. and Ph.D. (Program in Attitudes and Behavior) from the University of California, Berkeley. 



\title{
LEGAL AND ETHICAL CONSIDERATIONS IN GOVERNMENT COMPENSATION PLANS: A CASE STUDY OF SMALLPOX IMMUNIZATION
}

\author{
Naomi Seiler* \\ Holly Taylor ${ }^{* *}$ \\ Ruth Faden ${ }^{* * *}$
}

\section{INTRODUCTION}

How did we get here? How did we get to this deeply flawed policy creating so much frustration for families struggling in the present and with no plan for the future? We got here, we would argue, because we never paused for a key philosophical debate. It takes more than three days to face the kind of questions that arise from a different sort of war. What is our government's responsibility for its citizens-and what are the limits of that responsibility? Is it the government's role to compensate victims in the first place? And if so, exactly how? ${ }^{1}$

New York Times reporter Lisa Belkin wrote these words in December of 2002, at the conclusion of an article exploring the September 11th Victim Compensation Fund ("911 Fund") and the reactions of family members to the course that the program took. With over a year's perspective on the events, Belkin saw that the hastily-constructed compensation program, administered with the best of intentions, was lacking coherence of design and aim.

Five days after Belkin's article appeared, President Bush announced his Administration's proposal for a smallpox immunization plan. ${ }^{3}$ Fears that stockpiles of the virus could fall into the hands of terrorists or enemy nations had driven the development of a program to vaccinate "frontline" healthcare workers and, later, portions of the public. Despite the risk of severe side effects, the plan contained no clear articulation of a compensation policy in

* Greenwall Fellow in Bioethics and Health Policy, Bloomberg School of Public Health, Johns Hopkins University.

** Assistant Research Professor, Department of Health Policy and Management, Bloomberg School of Public Health and Core Faculty, Phoebe R. Berman Bioethics Institute, Johns Hopkins University.

*** Philip Franklin Wagley Professor of Biomedical Ethics and Executive Director Phoebe R. Berman Bioethics Institute, Johns Hopkins University.

1. Lisa Belkin, Just Money, N.Y. TIMES, Dec. 8, 2002, (Magazine), at 92.

2. Air Transportation Safety and System Stabilization Act, Pub. L. No. 107-42, § 403, 115 Stat. 237, 237 (2001).

3. See President George W. Bush, Remarks by the President on Smallpox Vaccination (Dec. 13, 2002), available at http://www.whitehouse.gov/news/releases/2002/12/200212137.html. 
the event of injury or death. ${ }^{4}$ The only mention of the issue appeared in an annex, which stated that one federal responsibility that "may be added" was "assessing the need for and scope of a suitable liability program for vaccine manufacturers and persons administering the vaccine." 5

Fearing that a lack of deliberation would cause problems like those seen with the 911 Fund, we began writing this Article with the intention of outlining recommendations for a policy to compensate people injured or killed in a smallpox immunization scheme. We sought to identify the legal, ethical, and practical questions that must be addressed in order to answer the fundamental question: What, if anything, does our government owe to people injured by a bioterrorism attack or by attempts to prepare for such an attack?

Since we began our research, the situation has changed. On October 15, 2003, the Director of Smallpox Preparedness and Response at the Centers for Disease Control and Prevention ("CDC") announced that the program had effectively ended: "The fact is, it's ceased, ... not that anyone's issued an edict to say stop." "Far fewer healthcare workers than expected had been immunized; the already-slow pace dropped sharply after several vaccinees died of heart problems. ${ }^{7}$ Although states had initially planned to immunize 450,000 workers, the total count of vaccinees is less than $40,000{ }^{8}$

This Article, therefore, is not a proposal, but rather, it presents a case study of how a compensation program for the smallpox immunization scheme should have been contemplated and provides a framework for contemplating similar programs. It is difficult to draw lessons from the recent immunization campaign because of its limited scope. However, the collapse of the program does underscore the importance of compensation: one explanation given for the low participation rates by healthcare workers was the lack of a compensation plan. ${ }^{9}$

Our goal is not to outline a detailed plan, but to analyze the questions that should have been asked early in the program's development. This analysis, and our illustration of how the analysis could have been applied to smallpox, yields lessons for any government compensation scheme and holds profound implications for public health and the principles it reflects. What is the government's responsibility when its citizens are harmed by outside forces or by our own efforts at protection? If we implement a system that sacrifices

\section{Id.}

5. Ctrs. for Disease Control \& Prevention, Annex 5: Suggested Pre-Event Activities for State and Local Public Health Authorities (May 21, 2003), A4-3.

6. Anita Manning, Smallpox Vaccination Plan 'Ceased'; Program is Cog of Bioterror Response, USA TODAY, Oct. 16, 2003, at A01.

7. Id. The heart problems have not been definitively linked to the vaccinations. See infra notes $92-93$ and accompanying text.

8. Id.

9. Alicia Ault, US Smallpox Vaccine Programme Stalls as Volunteers Balk, 361 LANCET 1626,1626 (2003). 
the health or lives of an unpredictable few for the good of many, how should we allocate the costs that fall on those few?

Part I offers background on smallpox: its causes, effects, and the history of efforts to prevent and then eradicate it. Part II continues with an overview of the Bush Administration's development of a smallpox immunization plan and traces the course that the program has taken. In Part III, we analyze the ethical, legal, and practical questions that arise in the creation of a compensation program. We incorporate examples of past government compensation schemes-most related to public health-to consider how these questions can and should be answered. In Part IV, we illustrate how these questions could have been addressed in the current smallpox immunization policy. We conclude with recommendations for future public health-related government compensation policies. While the smallpox case is most directly translatable to other disease-related harms, the issues it raises are relevant to any government compensation program.

\section{THE DISEASE}

Prior to its eradication in nature in $1980,{ }^{10}$ smallpox was responsible for millions of deaths annually worldwide. ${ }^{11}$ Smallpox is transmitted by exposure to respiratory droplets from someone with the virus or to infected clothing and bedding. ${ }^{12}$ Once infected, individuals experience a latent phase of four to fourteen days, during which they are not infectious but the virus is rapidly multiplying in their bodies. ${ }^{13}$ This latent period is followed by a phase characterized by headache, backache, and fever. ${ }^{14}$ During this time, the virus begins to infect the mucus membranes in the mouth and pharynx, and infected individuals become able to transmit the virus to others. ${ }^{15}$ Finally, the virus infects the skin, and pox appear over the entire body. ${ }^{16}$ The individual remains infectious for seven to ten days after the pox appear on the skin. ${ }^{17}$

There is no effective treatment for smallpox. ${ }^{18}$ If given within four days of infection, the smallpox vaccination is likely to mitigate the severity of the disease. ${ }^{19}$ In addition, if a case of smallpox appeared today, physicians might prescribe a strong antiviral medication, Cidofovir, currently approved for cyto-

10. Joel G. Breman \& D.A. Henderson, Diagnosis and Management of Smallpox, 346 NEW ENG. J. MED. 1300, 1300 (2002).

11. WORLd Health ORG., SMAllPOX ERAdication-A Global FirSt (1998), at http://www.who.int/archives/who50/en/smallpox.htm (last visited Feb. 6, 2004).

12. Breman \& Henderson, supra note 10, at 1302.

13. Id. at 1300.

14. Id.

15. Id. at 1300-01.

16. Id. at 1301 .

17. Id. at 1302. Donald A. Henderson et al., Smallpox as a Biological Weapon: Medical and Public Health Management, 281 JAMA 2127, 2129 (1999).

18. Breman \& Henderson, supra note 10, at 1302.

19. Id. at 1304. 
megalovirus but not smallpox. However, Cidofovir has serious side effects, and there is no evidence that giving Cidofovir is any more effective than postexposure vaccination. ${ }^{20}$ Untreated smallpox has a case fatality rate of $30 \% .^{21}$ Variola minor, a milder form of smallpox, has a case fatality rate of $1 \% .^{22}$

Smallpox vaccination was routine in the United States until 1972. Routine smallpox vaccination was halted in the United States when declining prevalence of the disease made the risks of vaccination outweigh the likelihood of exposure to the virus. ${ }^{23}$ The smallpox vaccine used in the 1960 s, which remains in use today, is prepared from live vaccinia virus rather than live smallpox virus; therefore, there is no risk of infection with smallpox as a result of vaccination. ${ }^{24}$ Dryvax vaccine (manufactured by Wyeth Laboratories) is the only smallpox vaccine currently licensed for use in the United States. ${ }^{25}$ Acambis/Baxter is currently under contract with the CDC to produce additional vaccine. That stock is expected to be licensed in 2004 if shown to be equivalent to Dryvax in clinical testing. ${ }^{26}$

The most comprehensive adverse event profile for smallpox vaccination is based on data collected during routine smallpox vaccination in the $1960 \mathrm{~s}^{27}$ Based on the experience of over thirteen million vaccinations, the risk of death as a result of vaccination is one in one million. ${ }^{28}$ Of those experiencing complications post-vaccination (seventy-four per one million), $68 \%$ were primary vaccinees, $7 \%$ re-vaccinees, and $20 \%$ had contact with a vaccinee. ${ }^{29}$ Lifethreatening complications included eczema vaccinatum, progressive vaccinia, and postvaccinial encephalitis. Vaccinia immune globulin ("VIG") is recommended for the treatment of most adverse events, ${ }^{30}$ but there is currently no treatment available for postvaccinial encephalitis. ${ }^{31}$ Other antibacterial and

20. Id. at 1302-04; Henderson et al., supra note 17, at 2132.

21. Henderson et al., supra note 17, at 2127.

22. Id. at 2129.

23. Michael R. Albert et al., The Last Smallpox Epidemic in Boston and the Vaccination Controversy, 1901-1903, 344 NEW ENG. J. MED. 375, 378 (2001).

24. Vincent A. Fulginiti et al., Smallpox Vaccination: A Review, Part I. Background, Vaccination Technique, Normal Vaccination and Revaccination, and Expected Normal Reactions, 37 CLINICAL INFECTIOUS DISEASES 241, 243 (2003).

25. Id.; CTRS. FOR DISEASE CONTROL \& PREVENTION, Vaccinia (Smallpox) Vaccine: Recommendations of the Advisory Committee on Immunization Practices (ACIP), 50(RR-10) MORBIDITY \& MORTALTTY WKLY. REP. 1, 3 (2001) [hereinafter CDC, Recommendations of ACIP].

26. Fulginiti et al., supra note 24, at 243-44.

27. See J. Michael Lane et al., Complications of Smallpox Vaccination, 1968: National Surveillance in the United States, 281 NEW ENG. J. MED. 1201 (1969).

28. Id. at 1206.

29. Id. at 1203.

30. CTRS. FOR DISEASE CONTROL \& PREVENTION, Smallpox Vaccination and Adverse Reactions: Guidance for Clinicians, 52(RR04) MORBIDITY \& MORTALTYY WKLY. REP. 1, 23 (2003) [hereinafter CDC, Guidance].

31. Vincent A. Fulginiti et al., Smallpox Vaccination: A Review, Part II. Adverse Events, 37 CLINICAL INFECTIOUS DISEASES 251, 268 (2003). 
antiviral therapy may be recommended depending on the type of adverse event or if there is no response to VIG. ${ }^{32}$

In addition to the direct risks of vaccination, those who are indirectly exposed to vaccinia virus are also at risk for adverse events. ${ }^{33}$ Although transmission of vaccinia virus is rare, those who come in direct contact with someone who has been vaccinated and is actively shedding vaccinia virus (from a vaccine site that is not fully healed) are at risk for infection with the vaccinia virus (inadvertent inoculation) and for eczema vaccinatum. ${ }^{34}$ There is little or no evidence that otherwise healthy individuals will experience severe side effects as a result of their exposure to vaccinia virus. ${ }^{35}$ VIG treatment is not recommended for those infected with vaccinia virus and who are otherwise healthy. ${ }^{36}$

In comparison with the smallpox virus itself, airborne transmission of vaccinia virus is unlikely, but possible. ${ }^{37}$ Cases of airborne transmission have been attributed to cases of vaccinia-related tonsillitis after vaccination with a more reatogenic vaccine than that used in the United States, and after exposure to a hospitalized case of eczema vaccinatum. ${ }^{38}$ Noting that the latter cases of infection could have occurred as a result of "fomites or the hands of [health care workers]," Lane and Fulginiti conclude that airborne transmission of vaccinia from normal vaccinations is doubtful. ${ }^{39}$

The last naturally-occurring case of smallpox in the United States was reported in 1949, and the mass vaccination programs in the United States were halted in $1972 .^{40}$ As a result, few Americans under thirty years of age have been vaccinated. ${ }^{41}$ Those adults who were vaccinated as children have likely lost any protection from infection with smallpox, but are expected to experience a milder form of the disease if infected. ${ }^{42}$ Recent evidence indicates that those vaccinated in the past may produce an antibody response to the smallpox virus for up to seventy-five years after vaccination, but it is unclear whether the ability to mount an antibody response constitutes full protection against infection. ${ }^{43}$

32. CDC Guidance, supra note 30 , at 24.

33. J. Michael Lane \& Vincent A. Fulginiti, Transmission of Vaccinia Virus and Rationale for Measures for Prevention, 37 CLINICAL INFECTIOUS DISEASES 281 (2003); John M. Neff et al., Contact Vaccinia - Transmission of Vaccinia from Smallpox Vaccination, 288 JAMA 1901 (2002); Kent A. Sepkowitz, How Contagious is Vaccinia?, 348 NEW ENG. J. MED. 439 (2003).

34. Neff et al., supra note 33, at 1903-04.

35. Id. at 1903.

36. CDC, Guidance, supra note 30 , at 22.

37. Lane \& Fulginiti, supra note 33, at 283; Sepkowitz, supra note 33, at 445.

38. Lane \& Fulginiti, supra note 33 , at 282.

39. Id. at 283.

40. Neff et al., supra note 33, at 1903.

41. Id.

42. Henderson et al., supra note 17, at 2132; Fulginiti et al., supra note 24, at 243.

43. Erika Hammarlund et al., Duration of Antiviral Immunity After Smallpox Vaccination, 9 NATURE MED. 1131 (2003). 
After the eradication of naturally-occurring smallpox virus, there was an effort to destroy all remaining stocks or to ship them to one of two secure research labs. ${ }^{44}$ By the late 1980 s, the only known stocks that remained were held at the CDC in Atlanta, Georgia and the Research Institute of Viral Preparations in Moscow, Russia, which later moved its specimens to the State Research Center for Virology and Biotechnology ("SRCVB") in Novosibirsk, Russia. ${ }^{45}$ In the 1990s, the World Health Organization ("WHO") coordinated discussions about whether to destroy the remaining stocks of smallpox virus. ${ }^{46}$ After deliberations in 1999, the WHO Committee on Variola Virus Research reaffirmed a previous decision to destroy the remaining stocks, but deferred destruction to allow further research on the virus, adding that research on the virus "should, under no circumstances, continue beyond the end of 2002."47

\section{RECENT U.S. SMALLPOX VACCINATION PLANS}

The terrorist attacks of 2001 and the anthrax deaths that occurred soon after changed the course of smallpox policy. ${ }^{48}$ Questions about the security of Russian labs after the fall of the Soviet Union, combined with concerns that all countries may not have destroyed their smallpox virus stocks, led to the fear that smallpox virus may have fallen into the hands of rogue nations or terrorist organizations. ${ }^{49}$ In May 2002, the World Health Assembly ("WHA") announced that research on the smallpox virus would continue. ${ }^{50}$ A report of deliberations by the WHO Committee in November 2002 notes progress in the development of new diagnostics, drugs, and vaccines for smallpox. ${ }^{51}$ With a heightened sense of its own vulnerabilities, the United States launched a program to prepare for a potential smallpox attack.

In early 2002, the public health and national defense communities within the Bush Administration actively debated whether to vaccinate a core group of healthcare workers and other critical personnel-a control and containment

44. Henderson et al, supra note 17 , at 2128 .

45. Breman \& Henderson, supra note 10 , at 1300.

46. WORLDHEALTHORG., WHOAdvisory Committee on Variola Virus Research: Report of a WHO Meeting, WHO/CDS/CSR/2000.1, (Dec. 6-9, 1999), available at http://www.who int/emc-documents/viral_diseases/docs/whocdscsr20001.pdf.

47. Id. at 11.

48. Authony Fauci, Smallpox Vaccination Policy - The Need for Dialogue, 346 NEWENG. J. MED. 1319 (2002); Fulginiti et al., supra note 24, at 241.

49. William J. Bicknell, The Case for Voluntary Smallpox Vaccination, 346 NEW ENG. J. MED. 1323, 1323 (2002); Fauci, supra note 48, at 1319.

50. FIFTY-FIFTH WORLD HEALTH ASSEMBLY, Smallpox Eradication: Destruction of Variola Virus Stocks, WHA55.15, (May 18, 2002), available at http://www.co.thurston.wa.us/ health/phep/documents/WHO\%202002\%20decision\%20on\%20destruction\%20of\%20Small pox\%20Stock.pdf.

51. WORLD HEALTH ORG., WHO Advisory Committee on Variola Virus Research: Report of the Fourth Meeting, WHO/CDS/CSR/2000.1, (Nov. 20-21, 2002), available at http://www. who.int/csr/resources/publications/viral/whocdscsrgar20035.pdf. 
strategy $\longrightarrow$ or to initiate a program to vaccinate the general population. ${ }^{52}$ In June 2002, the Advisory Committee on Immunization Practices ("ACIP"), a standing advisory group to the CDC, recommended that 20,000 health care and other critical personnel be vaccinated for smallpox in order to respond in case of a smallpox attack. ${ }^{53}$ Their recommendation of only a focused immunization campaign was based on the assumption that the risk of serious adverse events in a general-population campaign outweighed the risk of a smallpox outbreak. These recommendations updated their previous recommendations presented in June 2001. ${ }^{54}$

The 2001 ACIP recommendations focused on the vaccination of lab workers to protect them from exposure to orthopoxviruses, but introduced a number of issues and considerations in anticipation of the intentional release of smallpox as a bioweapon. ${ }^{55}$ After a spate of rumors that the Bush Administration had plans to recommend vaccination for many frontline workers, ACIP revised their recommendations to suggest the vaccination of up to 500,000 health care workers and other critical personnel in October 2002. ${ }^{56}$

On December 13, 2002, President Bush announced the Administration's smallpox vaccination plan. ${ }^{57}$ The plan included the immediate and mandatory vaccination of up to 500,000 military personnel; voluntary vaccination of up to 500,000 health care workers and other critical personnel to start forming Smallpox Response Teams on January 24, 2003 (the effective date of the Homeland Security Act); to be followed by vaccination of up to ten million first responders. In addition, the President announced that the Administration would make unlicensed ${ }^{58}$ vaccines available to otherwise healthy members of the general population who insist on access. ${ }^{59}$

52. Jon Cohen \& Martin Enserink, Rough-and-Tumble Behind Bush's Smallpox Policy, 298 SCIENCE 2312, 2312 (2002).

53. CTRS. FOR DISEASE CONTROL \& PREVENTION, Record of the Meeting of the Advisory Committee on Immunization Practices, (June 19-20, 2002), available at http://www.cdc.gov/nip/acip/minutes/acip-min-jun02.pdf; Ceci Connolly, Smallpox Vaccine Program Readied: Inoculations May Surpass 500,000 Under U.S. Plan, WASH. POST, July 8, 2002, at A01.

54. CDC, Recommendations of ACIP, supra note 25 , at 3.

55. Id.

56. Lawrence K. Altman, Threats and Responses: Biological Readiness; Smallpox Inoculation Urged for Employees of Hospitals, N.Y. TIMES, Oct. 17, 2002, at A20; David Brown, Limited Smallpox Vaccine Use Eyed; Expert Panel Rejects Mass Inoculations, WASH. POST, June 21, 2002, at A01; Cohen \& Enserink, supra note 52, at 2312; Voluntary Smallpox Vaccination Urged: Offer to General Population Represents a Shift in Policy, WASH. POST, Oct. 5,2002 , at A01.

57. Bush, supra note 3.

58. The vaccine will be unlicensed until 2004. Fulginiti et al., supra note 24, at 243.

59. Bush, supra note 3. 


\section{A. Lack of a Compensation Plan}

On the day the national smallpox vaccination campaign was announced, there was no federal program in place to compensate those individuals vaccinated or exposed to vaccinia for injury, or to compensate their families in the case of death. The Homeland Security Act, signed in November 2002, removed liability for injury from vaccine manufacturers and individuals and institutions who would be administering vaccinations. ${ }^{60}$ Any injured vaccinees would have to sue the Federal government under the Federal Tort Claims Act and prove negligence to receive compensation. ${ }^{61}$

With the initial vaccinations set to commence on January 24,2003 , healthcare union and professional associations began to voice concern about the lack of provisions for injury compensation. ${ }^{62}$ A number of hospitals refused to begin the vaccination of their employees until the issue of compensation was resolved. ${ }^{63}$ Concerns were multiple: workers' compensation programs might not cover injuries sustained by an employee who volunteers to be vaccinated, medical expenses related to injuries sustained might not be covered by health insurance, income and staff might be lost for days if employees needed to recover from adverse events, and patients might sustain injuries from indirect exposure to vaccinia. ${ }^{64}$ Despite these concerns, the Washington Post reported that as of January 2003, the Bush Administration would not be creating a compensation fund to cover these costs. ${ }^{65}$ The Institute of Medicine ("IOM"), asked by the CDC to consult on implementation of the smallpox vaccination program, cautioned that the "currently stated plans for compensation for adverse reactions could seriously affect achievement of the stated goal of the program - to increase the nation's bioterrorism preparedness." 66

Further complicating the picture was the fact that previous smallpox vaccination programs focused on children, who generally received the vaccine (2002).

60. Homeland Security Act of 2002, Pub. L. No. 107-296, $\$ 304,116$ Stat. 2135, 2165-67

61. Joan Stephenson, Smallpox Vaccine Program Launched Amid Concerns Raised by Expert Panel, Unions, 289 JAMA 685, 685 (2003).

62. AAEM/SAEM SMALLPOXVACCINATIONWORKING GROUP, Smallpox Vaccination for Emergency Physicians, 10 ACAD. EMERGENCY MED. 681, 682 (2003); Letter from American Federation of State, County and Municipal Employees to President Bush (Jan. 16, 2003), available at $\mathrm{http}: / / \mathrm{www} . \mathrm{afscme} .0 \mathrm{rg} / \mathrm{action} / 1030116 \mathrm{htm}$; Letter from Barbara A. Blakeney, American Nurses Association, to President Bush (Jan. 16, 2003), available at http://www.nursingworld.org/pressre1/2003/tr0116.htm; Ray Moynihan, Health Professionals Challenge US Smallpox Vaccination Plan, 326 BRIT. MED. J. 179 (2003).

63. Julie Piotrowski, Smallpox, Big Worries, 33 MODERN HEALTHCARE 6, 7 (2003).

64. INST. OF MED., Review of the Centers for Disease Control and Prevention's Smallpox Vaccination Program Implementation, Letter Rep. 1 (Jan. 16, 2003).

65. Ceci Connolly, Caregivers Protected Against Smallpox Lawsuits; Bush Plan Would Not Compensate Patients for Vaccine's Side Effects or Accidental Exposure to Virus, WASH. PosT, Jan. 15, 2003, at A14.

66. INST. OF MED., supra note 64 , at 8. 
after their first birthday. ${ }^{67}$ By contrast, the current smallpox vaccination program targeted adults who, both because of the age-related burden of disease and subsequent changes in public health and advances in medicine, are more likely than participants in earlier vaccination campaigns to be immunocompromised, either because of HIV/AIDS or treatment for transplant rejection or cancer. ${ }^{68}$ Immunocompromised individuals are more likely to experience severe adverse events due to smallpox vaccination than individuals with healthy immune systems. ${ }^{69}$ Those who have eczema are also more likely to experience more severe adverse events from smallpox vaccination. ${ }^{70}$ In the absence of an actual release of smallpox, pregnant women should not be vaccinated, given the risks of fetal infection. ${ }^{71}$ In addition, anyone who has close contact with a person for whom vaccination is contraindicated should also avoid pre-release vaccination, as they could transmit the vaccinia virus. ${ }^{72}$ Because of these and other concerns, efforts are underway to produce safer vaccine products. ${ }^{73}$

Congressman Henry Waxman and a number of his congressional colleagues sent a letter to the White House on January 17, 2003 in response to the aforementioned report in the Washington Post. In that letter, Congressman Waxman and his colleagues called on the Bush Administration to create a "nofault" compensation plan to compensate anyone harmed as a result of smallpox vaccination or exposure to vaccinia. ${ }^{74}$ On February 13, 2003, Congressman Waxman introduced HR 865, the Smallpox Vaccine Compensation and Safety Act of 2003, which authorized no-fault compensation for injury, grants to states to cover the implementation of the vaccine program, protection from discrimination for individuals who refuse vaccination, and coverage of costs of up to four days of leave for health care workers who experience short-term adverse events. ${ }^{75}$

67. Alex R. Kemper et al., Expected Adverse Events in a Mass Smallpox Vaccination Campaign, 5 EFFECTIVE ClinICAL PRAC. 84, 85 (2002).

68. Neff et al., supra note 33, at 1903.

69. Sepkowitz et al., supra note 33, at 443-45; Neff et al., supra note 33, at 1904.

70. Neff et al., supra note 33, at 1903.

71. Kemper et al., supra note 67 , at 86.

72. Id.

73. News Release, DePT. OF HEALTH \& HUMAN SERVS., HHS Announces Contracts to Develop Safer Smallpox Vaccines (Feb. 25, 2003), available at http://www.hhs.gov/news/press/ 2003pres/20030225.html.

74. Letter from Congressman Henry Waxman to President George W. Bush 1 (Jan. 17, 2003), available at $\mathrm{http}: / / \mathrm{www}$.house.gov/reform/ $\mathrm{min} / \mathrm{pdfs} / \mathrm{pdf}$ _com/pdf_health_vaccine_small pox_bush_let.pdf.

75. Statement of Rep. Henry A. Waxman on the Introduction of the Smallpox Vaccine Compensation and Safety Act of 2003 (Feb. 13, 2003), available at http://www.house.gov $/$ reform/min/pdfs/pdf_com/pdf_homeland_security_legis_state.pdf. 
On March 5, 2003, the Department of Health and Human Services ("HHS") announced its own compensation proposal. ${ }^{76}$ The HHS proposal was modeled on the Public Safety Officers Benefit ("PSOB") plan. It created a system of specific dollar amounts to be offered to smallpox vaccinees and those injured by exposure to vaccinia in cases of temporary and permanent disability and death. ${ }^{77}$ It also created funds to supplement coverage of medical expenses not covered by the individual vaccinees' medical insurance. ${ }^{78}$ The law that ultimately passed, the Smallpox Emergency Personnel Protection Act of $2003,{ }^{79}$ was built on the HHS proposal.

\section{B. Current Adverse Event Profile}

Since the initiation of the smallpox vaccination program, the Department of Defense ("DOD") and the CDC have been keeping careful records of adverse events. After 450,293 vaccinations of military personnel, no deaths have occurred, but two cases of encephalitis and twenty-one cases of contact transfer have been reported. ${ }^{80}$ Of note, among other possible side effects is myopericarditis, which was not routinely reported during the last smallpox vaccination campaign. ${ }^{81}$ A possibility exists that current diagnostic techniques are responsible for identification of these events as coincident with vaccination. ${ }^{82}$ The absence of reported cases of eczema vaccinatum is attributed to rigorous screening practices. ${ }^{83}$ Despite the rigorous screening, however, ten HIV-infected men were vaccinated without incident and eighty-five pregnant women were vaccinated. ${ }^{84}$ There have been no cases of transmission in the military health care setting from vaccinees to other patients. ${ }^{85}$

According to the CDC, during the period covering January 24 to June $20,2003,37,802$ civilian health care and public health workers were vaccinated for smallpox; no deaths have been directly attributed to the smallpox

76. Press Release, Dep't of Health \& Human Servs., HHS Proposes Smallpox Vaccination Compensation Plan (Mar. 5, 2003), available at http://www.hhs.gov/news/press/ 2003pres/20030305.html; Ceci Connolly, Smallpox Compensation Proposed: White House Agrees to Benefits for Health Care Workers Sickened by Vaccine, WASH. POST, Mar. 6, 2003, at $\mathrm{A} 01$.

77. DEP'T OF HEALTH \& HUMAN SERVS., supra note 76.

78. Id.

79. Smallpox Emergency Protection Act of 2003, Pub. L. No. 108-20, 117 Stat. 638 (codified as amended in scattered sections of 42 U.S.C.).

80. John D. Grabenstein \& William Winkenwerder, US Military Smallpox Vaccination Program Experience, 289 JAMA 3278 (2003). Other adverse events reported include: thirtyeight cases of autoinoculation, thirty-seven cases of myopericarditis, thirty-six cases of generalized vaccinia and one case of erythema multiforme. Id. at 3280-81.

81. Id. at 3281 .

82. Id.

83. Id.

84. Id.

85. Grabenstein \& Winkenwerder, supra note 80 , at 3281. 
vaccination. ${ }^{86}$ Serious side effects include one suspected case of encephalitis and seventeen suspected cases of myopericarditis. ${ }^{87}$ As with the military experience to date, no cases of eczema vaccinatum have been reported ${ }^{88}$ The absence of this side effect has also been attributed to strict screening practices. ${ }^{89}$ There have also been no reported cases of vaccinia transmission to a person in close contact with the vaccinee..$^{90}$ Six civilian women have been exposed to the vaccine during pregnancy, and no transmission from vaccinees to other patients has occurred. ${ }^{91}$

In addition, there has been extensive attention to a number of heartrelated complications. The CDC reports that there have been eight cases of ischemic heart disease to date, including five myocardial infarctions (two fatal) and three cases of angina. ${ }^{92}$ An investigation as to whether these cases were vaccine-related is ongoing, but to date a link has not been shown. ${ }^{93}$

\section{Current Efforts to Vaccinate Healthcare Workers}

Vaccination efforts moved more slowly than anticipated, ${ }^{94}$ partly because states were given little time to prepare for the vaccination program. ${ }^{95}$ President Bush announced his plans in mid-December 2002 and states were to begin vaccinating public health disease investigators and hospital-based teams of health care workers in late January 2003. ${ }^{96}$ Healthcare workers and hospitals raised concerns about lack of appropriate mechanisms for compensation for injury ${ }^{97}$ Hospitals were also concerned about placing their staff, staff families, and patients at risk of injury in response to an indeterminate threat of a smallpox attack. ${ }^{98}$ All of these concerns were compounded by the reports of unanticipated cardiac adverse events among vaccinees noted above. ${ }^{99}$ Finally, concerns about a smallpox attack have also waned as the primary

86. CTRS. FOR DiseASE CONTROl \& PREvention, Cardiac and Other Adverse Events Following Civilian Smallpox Vaccination - U.S. 2003, 52 MORBIDITY \& MORTALTTY WKLY. REP. 639, 639 (2003) [hereinafter CDC, Adverse Events I].

87. Id. Confirmed reports of other adverse events include: eight cases of inadvertent inoculation, two cases of ocular vaccinia, and one case of generalized vaccinia. Id. at 640 .

88. Id.

89. Id.

90. Id.

91. CDC, Adverse Events I, supra note 86, at 640.

92. Id.

93. Id. at 641-42; CTRS. FOR DISEASE CONTROL \& PREVENTION, Cardiac Adverse Events Following Smallpox Vaccination-United States 2003, 52 MORBIDITY \& MORTALITY WKLY. REP. 248 (2003).

94. U.S. GEN. ACCOUNTING OFFICE, GAO-03-578, SMALLPOX VACCINATION: IMPLEMENtATION OF NATIONAL PRogRam FACES ChALLENGES 4 (Apr. 30, 2003).

95. Id.; INST. OF MED., supra note 64.

96. INST. OF MED., supra note 64, at 2-3.

97. U.S. GEN. ACCOUNTING OFFICE, supra note 94, at 21.

98. Id. at 18.

99. Ault, supra note 9, at 1626. 
assault on Iraq ended. ${ }^{100}$ While it is possible that the rate of vaccination may increase again since the program has not been formally halted, any momentum that could have been gained by prospectively addressing these issues may have been lost.

\section{ETHICAL AND LEGAL CONCERNS IN COMPENSATION}

This section traces the key legal and ethical questions to be asked in designing a compensation program. To provide both historical context and concrete examples, we illustrate each concern with past U.S. government compensation programs.

\section{A. Was the Government the Actor Who Caused the Harm?}

Under tort law, the tortfeasor pays the victim. The two rationales most commonly offered are compensation ${ }^{101}$ and deterrence. ${ }^{102}$ The person who commits a harm should bear the cost of that harm. Presumably, the fear of a penalty will have both a specific deterrent effect on the tortfeasor in question and a general deterrent effect on other parties. Government compensation programs arguably fit well into this model when the government itself has directly caused harm to its citizens or to others. However, should the federal government fund a compensation program when the harm is directly or indirectly caused by a third party?

Although not a single coordinated system, crime victim compensation programs are an example of government compensation to victims despite the contribution of others to the harm. ${ }^{103}$ Every state has a version of this program, supported by funds from offenders, state funds, and federal funds authorized by the Victims of Crime Act of 1984 ("VOCA"). ${ }^{104}$ Although eligibility requirements vary, all states have the same basic criteria. ${ }^{105}$ The victim generally must report the crime promptly to law enforcement, cooperate in the investigation and prosecution of the case, submit a timely applica-

100. Id.

101. See William L. PROSSER, HANDBoOK OF THE LAW OF TORTS 7 (4th ed. 1971).

102. See Gary T. Schwartz, Reality in the Economic Analysis of Tort Law: Does Tort Law Really Deter?, 42 UCLAL. REV. 377, 378 (1994); Howard A. Latin, Problem-Solving Behavior and Theories of Tort Liability, 73 CAL. L. REV. 677, 677 (1985) ("The most influential mode of torts analysis in recent decades has treated liability as a mechanism for social engineering in the sense that accident losses should be allocated to particular parties in order to induce efficient cost-minimizing behavior by similarly situated actors.").

103. See NAT'L ASS'N OF CRIME ViCTIM COMP. BDS. (NACVCB), Crime Victim Compensation: An Overview, at http://www.nacvcb.org/articles/Overview_prn.html (last visited Feb. 2, 2004).

104. Id.; See NAT'LASs'N OFCRIME VICTIM COMP. BDS. (NACVCB), Program Directory, at http://www.nacvcb.org/progdir.html (last visited Feb. 2, 2004).

105. NAT'L ASS'N OF CRIME VICTIM COMP. BDS., supra note 103. 
tion to the program, and experience a cost or loss not covered by insurance. ${ }^{106}$ Victims must also generally be innocent of any misconduct that contributed to the injury incurred. ${ }^{107}$ State programs usually cover the same major types of expenses, including medical, mental health counseling, lost wages, lost support, and funeral expenses. ${ }^{108}$ Despite the breadth of these payment categories, maximum benefits available to victims from the programs generally range between $\$ 10,000$ and $\$ 25,000$. $^{109}$

Why should the government compensate people for crimes committed against them not by the government, but by other individuals? One explanation is that the government is acting not out of obligation but out of compassion. Many offenders are judgment-proof, and a state fund may be the only way for a victim to recover some expenses from injury. An alternate interpretation is that the state government failed in its duty to protect people from crime. Accordingly, it is obligated to compensate crime victims for the harms that they suffered due to lack of adequate law enforcement.

Another example of a program designed to compensate citizens for harms not directly caused by government is the Federal Emergency Management Agency ("FEMA"). FEMA was created by President Jimmy Carter in 1979 to centralize federal emergency and disaster activities. ${ }^{110}$ Agencies that were combined into FEMA included not only the agencies working on fire and flood relief, but also the Defense Department's Defense Civil Preparedness Agency. ${ }^{111}$ According to FEMA's website:

[FEMA's first director John] Macy emphasized the similarities between natural hazards preparedness and the civil defense activities. FEMA began development of an Integrated Emergency Management System with an all-hazards approach that included "direction, control and warning systems which are common to the full range of emergencies from small isolated events to the ultimate emergency-war." 112

FEMA's responsibility is to prevent and respond to disasters when state and local governments are not sufficient. ${ }^{113}$ Under the Stafford Act, ${ }^{114}$ the

106. $I d$.

107. Id.

108. Id.

109. Id.

110. FED. EMERGENCY MGMT. AGENCY (FEMA), FEMA History, at http://www.fema. gov/about/history.shtm (last visited Feb. 3, 2004).

111. Id.

112. Id

113. FED. EMERGENCY MGMT. AGENCY, A Nation Prepared Federal Emergency Management Agency Strategic Plan, at http://www.fema.gov/pdf/library/fema_strat_plan_fy03-08 (append).pdf (last visited Mar. 20, 2004).

114. Stafford Act of 1974, 42 U.S.C. $\$ \$ 5121-5204$ (2003). 
governor of a state requests that the President declare the state a disaster area ${ }^{115}$ and the regional FEMA office does an assessment. ${ }^{116}$ If the President does declare an emergency, available assistance "is limited to immediate and short-term assistance, essential to save lives, to protect property and public health and safety, or to lessen or avert the threat of a catastrophe."117

Like the crime victim compensation programs, FEMA involves payments to individuals and businesses for acts that were not under the government's direct control. FEMA (now incorporated into the Department of Homeland Security ${ }^{118}$ ) serves an established role as a supporter of individuals and businesses in stricken communities. Here, too, one could argue that government failed in its duty to protect citizens from danger, although weather-related and other natural emergencies are clearly even further from government's control than criminal offenders. The more powerful conclusion, however, is that government responsibility for compensation does not stem solely from government-initiated harms.

\section{B. Was the Harm Foreseeable?}

In negligence suits, the harm must generally be a foreseeable consequence of the tortfeasor's actions in order for the plaintiff to prevail. ${ }^{119}$ When a suit involves the failure to take precautions to protect another from harm, a finding of negligence requires one to take precautions to prevent only those harms that are foreseeable. ${ }^{120}$ Government compensation programs have frequently recognized a greater level of responsibility to victims where the harms caused were foreseeable at the time of their incurrence.

The history of compensation for people who were infected with HIV from the blood supply is fraught with critiques of the federal government's failure to act despite the knowledge that such transmission could occur. ${ }^{121}$ In 1998, Congress established the Ricky Ray Hemophilia Relief Fund to make "compassionate payments" of $\$ 100,000$ to people with hemophilia and other clotting disorders who were treated with anti-hemophiliac factor between July

115. Id. $\S 5170,5191$.

116. Id. $\$ 5143(\mathrm{~b})(1)$.

117. FED. EMERGENCY MGMT. AGENCY, A Guide to the Disaster Declaration Process and Federal Disaster Assistance (Oct. 5, 2001), available at http://166.112.200.141/r-nr/dec_guid.htm. (2002).

118. Homeland Security Act of 2002, Pub. L. No. 107-296, § 503(1), 116 Stat. 2135, 2213

119. W. Page Keeton et AL., Prosser AND KeEton on the LAW of Torts $\S 43$ (5th ed. 1984).

120. Blythe v. Birmingham Waterworks, 11 Ex 781 (Ct. of Exchequer, 1856) (holding that because severe frost was unforeseeable, it was not negligent to fail to take precautions for it).

121. For a critique of the government's response to HIV in the blood supply, see DIv. OF HeALTH PROMOTION \& DisEASE PREVENTION, INST. OF MED., HIV and the Blood Supply: An Analysis of Crisis Decisionmaking (Oct. 1995). 
1, 1982 and December 31, 1987 and who contracted HIV. ${ }^{122}$ Spouses and children who subsequently contracted HIV and certain groups of survivors also received benefits. The payouts totaled over $\$ 554$ million to over 7100 eligible individuals and survivors by the program's closing date for petitions on November 13, 2001. ${ }^{123}$ Although the term "compassionate payments" suggests an altruistic regard for the victims as opposed to a sense of reparation, the government was highly criticized throughout the early to middle 1980 s for not taking steps to improve the safety of the blood supply, particularly the systems used to pool clotting factor components. ${ }^{124}$ The foreseeability of extremely high transmission rates can be seen as a tacit element of the government's role in compensating this community.

Foreseeability also played a major, explicit role in the retroactive analysis of the government's treatment of workers who mined uranium for the Atomic Energy Commission in the western United States from the 1940s to 1960s. ${ }^{125}$ The Advisory Committee on Human Radiation Experiments ("ACHRE"), convened by President Clinton in 1994, reported on the uranium miners' continued exposure to high levels of radioactive radon gas despite mounting evidence of very high cancer rates among uranium miners in Europe. ${ }^{26}$ A Public Health Service epidemiological study of the United States miners tracked their exposures but did not engage in clinical intervention or inform the miners of the risk of lung cancer to which they were exposed. ${ }^{127}$ Officials also did not take steps to ventilate the mines in a manner that would have reduced exposure. ${ }^{128}$ In assessing the acts and omissions of the government with regard to human radiation experiments, the ACHRE Committee identified the foreseeability of harm as the major root of the government's blameworthiness:

The Committee believes that after 1951, when [findings] established that miners were getting a much larger dose to the lungs than previously suspected, the mine owners, the state governments, and the federal government each had a

122. HEALTh RES. \& SERVS. AdMIN. (HRSA), Ricky Ray Hemophilia Relief Fund, at http://bhpr.hrsa.gov/rickyray/ (last visited Feb. 3, 2004).

123. Id.

124. See Div. OFHEALTH PROMOtION\& DiseASe PREVENTION, INST. OFMED., supra note 121.

125. U.S. DEP'T OF ENERGY, ACHRE REPORT, DOE OPENNESS: HUMAN RADIATION EXPERIMENTS: ROADMAP TO THE PROJECT, at http://tis.eh.doe.gov/ohre/roadmap/achre/ chap12_1.html (last visited Apr. 2, 2004).

126. Id.

127. Id.

128. Id. 
responsibility to take action leading to ventilation of all mines. ${ }^{129}$

The Advisory Committee has found no plausible justification for the failure of the federal government, which is the focus of our inquiry, to adhere to these principles. It is clear that officials of the federal government were convinced by the early 1950 s that radon and radon-daughter concentrations in the mines were high enough to cause lung cancer. The federal government's obligation flows from this knowledge and its causal link to the mining activity. ${ }^{130}$

Although the federal government had already established a compensation scheme for Uranium Miners in the Radiation Exposure Compensation Act of $1990,{ }^{131}$ the Committee recommended expanded compensation that would eliminate stringent exposure-linked eligibility requirements. ${ }^{132}$ Key to the Committee's recommendation was the foreseeability of the harms caused, given the information available at the time, ${ }^{133}$

\section{Was Exposure to the Harm Voluntary and Informed?}

In tort law, assumption of risk can preclude an award to a plaintiff. If a victim knowingly and voluntarily subjects herself to the risk of harm, she may not be able to recover for injuries incurred. ${ }^{134}$ Some states have comparative negligence schemes that minimize, but da not preclude, defendant liability when a plaintiff was contributorily negligent, ${ }^{135}$ Additionally, a plaintiff who assumed risk can generally still recover if she can show that the defendant broke a law that was designed to protect a class of people of which the plaintiff is a member. ${ }^{136}$ In a government compensation program, it is necessary to consider whether a victim's knowledge and voluntary assumption of risk should enhance, hinder, or not affect her ability to recover for her injuries.

Compensation programs for public safety officers respond in various ways to this issue. Most states place public safety officers into special

129. U.S. DeP'T OF ENERgY, ACHRE REPORT, CH. 12: THE URANIUM MineRS, at http://tis.eh.doe.gov/ohre/roadmap/achre/chap12_2.html (last visited Feb. 6, 2004).

130. Id.

131. Radiation Exposure Compensation Act of 1990, Pub. L. No. 101-426, 104 Stat. 920.

132. U.S. DEP'T OF ENERGY, ACHRE REPORT, supra note 129.

133. Id.

134. KEETON ET AL., supra note 119, § 68.

135. Id. § 67.

136. Id. $\$ 68$. 
workers' compensation programs with enhanced benefits. ${ }^{137}$ Knowledge that police and firefighting work are dangerous does not diminish the benefits that injured parties could recover. On the contrary, higher benefits are offered both to reward and incentivize choosing these lines of work.

In contrast, in most jurisdictions, assumption of risk does preclude public safety officers from recovering under tort law. ${ }^{138}$ The "fireman's rule" states that firefighters and their estates may not use tort law to sue the people whose negligence led to their injuries or death. ${ }^{139}$ There are several justifications for the fireman's rule, one of which is that firefighters voluntarily assume the risk of their jobs and therefore, are not entitled to compensation for any injuries incurred. ${ }^{140}$ As a California court stated in 1977:

The fireman's rule is based on a principle as fundamental to our law today as it was centuries ago. The principle is not unique to landowner cases but is applicable to our entire system of justice: one who has knowingly and voluntarily confronted a hazard cannot recover for injuries sustained thereby. ${ }^{141}$

\title{
D. Did the Harm Occur in the Context of an Attempt to Avert a Greater Harm?
}

\begin{abstract}
A basic utilitarian ethical analysis would hold that, all other things being equal, exposing people to harm is justified if a greater harm can thus be averted. However, does ethical justification of the risk exposure absolve those responsible of the obligation to compensate victims? The National Vaccine Injury Compensation Program ("NVICP") exists both to provide compensation to injured vaccinees ${ }^{142}$ and also to shield the vaccine industry from excessive and unpredictable liability. ${ }^{143}$ The program involves a table of presumptive injuries for which parents of injured children can seek compensa-
\end{abstract}

137. NAT'L ASS'N OF POLICE ORG. (Website), Statement for the Record of Robert T. Scully, Executive Director, National Association of Police Organizations, Submitted to the Subcommittee on Social Security of the Committee on Ways and Means United States House of Representatives on May 21, 1998, at http://www.retirementsecurity.org/Impact/Testimony/ imp_TestNAPO.htm (last visited Mar. 22, 2004) ("[M]ost governments have recognized that public safety officers need certain protections and benefits in recognition of the nature of their jobs.").

138. KEETON ET AL., supra note $119, \S 61$.

139. Id.

140. Id.

141. Walters v. Sloan, 571 P.2d 609, 612 (Cal. 1977), superceded by CAL. Crv. CoDE $\S$ 1714.9 (2004).

142. H.R. Rep. No. 99-908, at 6345-46 (1986).

143. Id. 
tion. ${ }^{144}$ Before the passage of the NVICP, parents of children injured by vaccines turned to tort law for compensation for their children's deaths or for funds to pay for their care if they were severely injured. ${ }^{145}$ Many polio plaintiffs, for example, sued under theories of manufacturer's negligence ${ }^{146}$ or breach of implied warranty. ${ }^{147}$

Despite developments partly shielding manufacturers from liability, ${ }^{148}$ lawsuits continued through the 1970s and 1980s and were perceived as a threat to the affordability and availability of vaccines. ${ }^{149}$ The NVICP, while providing a clear mechanism for compensation to children harmed by childhood vaccines, also sought to preserve the nation's vaccine supply and thereby maintain a population-level immunity to various childhood diseases. ${ }^{150}$

In what is essentially a mandatory childhood vaccination scheme (which mandates certain vaccinations for school attendance and then mandates school attendance), the unfortunate occurrence of side effects among a very small group of children arguably can be justified by the larger goal (and effect) of preventing high rates of illness and death from infectious disease. ${ }^{151}$ Accordingly, it might be plausible to say that the government has no obligation to compensate these children or their families. By providing a mandatory alternative to tort litigation, the NVICP strikes a balance that both acknowledges the ethical obligation to compensate and preserves an effective system of vaccination. ${ }^{152}$ In this instance, the ethical obligation to compensate is grounded in concerns about fairly distributing the burdens of what is de facto a mandatory vaccination program.

\section{E. Can Causation, and Subsequently Legal and/or Moral Responsibility, be Established?}

In tort law, for a plaintiff to recover, a negligent act must have been a "but-for" cause of harm, and also must have been the proximate cause of

144. U.S.GEN. ACCOUNTING OFFICE, GAO/HEHS-00-8, VACCINE INJURY COMPENSATION: Program Challenged to SeTtle Claims Quickly AND EASIl 1 (Dec. 22, 1999).

145. Id. at 4.

146. See, e.g., Griffin v. United States, 351 F. Supp 10 (E.D. Pa. 1972).

147. See, e.g., Gottsdanker v. Cutter Labs., 182 Cal. App. 2d 602 (Cal. Ct. App. 1960).

148. In 1965, the Second Restatement of Torts noted that drugs and vaccines include a particularly high number of products that are "unavoidably unsafe." RESTATEMENT (SECOND) OF TORTS $\S 402 \mathrm{~A} \mathrm{cmt.} \mathrm{k} \mathrm{(1965).} \mathrm{Their} \mathrm{marketing} \mathrm{and} \mathrm{use} \mathrm{are} \mathrm{"fully} \mathrm{justified,"} \mathrm{but} \mathrm{there} \mathrm{is} \mathrm{no}$ way that injuries can be entirely avoided. The "unavoidably unsafe" designation, quickly adopted by the courts, theoretically shielded manufacturers from liability if they prepared vaccines properly and gave adequate warnings. $I d$.

149. U.S. GEN. ACCOUNTING OFFICE, supra note 144, at 1.

150. Id. at 4-5.

151. Id. at 4.

152. Id. at 5. 
harm. ${ }^{153}$ When the causes of a person's injury or death are multiple or unclear, a compensation program must establish a method for determining causation. Lax guidelines may help victims, but they deplete a program's resources or dilute its purpose; rigid guidelines can exclude valid recipients from receiving compensation.

The NVICP, discussed above, deals with the issue of causation by creating categories of presumptive eligibility, as outlined in the Vaccine Table. ${ }^{154}$ If a certain injury or reaction occurs within a certain time period after vaccination, the plaintiff wins. ${ }^{155}$ If an injury occurs outside these parameters, the plaintiff may present evidence for causation, which the state can counter. ${ }^{156}$ Some cases are fairly easy to win. For example, a child who contracts polio after receiving a polio vaccination in a region without an outbreak was unlikely to have been infected any other way. Other reactions are more difficult to prove. For example, many DPT vaccine cases involve children who developed high fevers and seizures. Because such problems can be caused by underlying health issues, it can be difficult to prove that the vaccine was the cause of the injury, and the special master can use wide discretion in crediting or discrediting plaintiffs' evidence. ${ }^{157}$

Workers' compensation laws may also be used by healthcare workers to compensate for a vaccine-related injury. Workers' compensation laws are designed to ensure that employees who are injured on the job receive fixed monetary awards without having to litigate their claims against their employers. ${ }^{158}$ In this way, workers' compensation is a relatively predictable and reliable safety net for employees when they are injured on the job. ${ }^{159}$ Most workers' compensation laws also provide employers and co-workers with a certain level of protection by limiting the amount employees can recover from their employers and prohibiting, in most cases, injured employees from suing their co-workers. ${ }^{160}$ In essence, workers' compensation is a no-fault system, where an injured worker's own negligence, or the negligence of his or her employer or co-workers, is not put at issue; rather, the injured employee is simply covered for his or her work-related injuries. By turning the focus away from causation, worker's compensation and other nofault compensation programs make compensation more predictable and limit the effects of arbitrary or subjective decision-making on the award of funds.

153. N.Y. Central R.R. Co. v. Grimstad, 264 F. 334, 335 (2d Cir. 1920); Palsgraf v. Long Island R.R. Co., 162 N.E. 99, 101 (N.Y. 1928).

154. U.S. GEN. ACCOUNTING OFFICE, supra note 144, at 5.

155. Id. at 6.

156. Id.

157. Id. at 30.

158. KEETON ET AL., supra note $119, \S 80$.

159. Id.

160. Id. 


\section{F. Equity Concerns}

Equity among plaintiffs or victims is a common legal and ethical issue in litigation and compensation schemes. When plaintiffs litigate cases individually, wide variation in awards is common. ${ }^{161}$ Mass tort cases have the potential to mitigate disparities by pooling plaintiffs and distributing awards equitably. Similarly, government compensation schemes have the potential to minimize unfairness by addressing reparations at a group level, but inequities can still occur within and across compensation programs.

The 911 Fund $^{162}$ has generated frequent charges of unfairness. Central to these critiques are the methods used to calculate certain types of damages. Although some are standard, non-economic awards for death $(\$ 250,000$ for all victims' estates), others vary by individual victim. ${ }^{163}$ For example, because economic loss is calculated based on state wrongful death law, many formulas that take lost earnings into account will result in higher payments to the families of victims who had higher salaries. This sort of calculation, although common in tort law, is perceived as a great injustice by families of lower-paid victims and by observers who interpret the formula as valuing life discriminatorily. ${ }^{164}$

The Ricky Ray Relief Fund ${ }^{165}$ has also faced charges of unfairness, not based on internal inequalities, but because of its limited scope. Although the act provided compensation to hemophiliacs who contracted HIV from blood product transfusions, it did not cover non-hemophiliacs who also contracted HIV from blood:

'When I read the language of their original Ricky Ray Bill, I was furious,' says Steve Grissom, an army veteran who contracted AIDS from contaminated blood transfusions in 1985 and who founded the National Association for Victims of Transfusion-Acquired AIDS. 'This bill advanced the notion that only hemophiliacs contracted AIDS through contaminated blood products. We (transfusion victims) never existed, never happened. All the while, many of us were suffering, many more of us died. Ricky Ray was a good kid.

161. David W. Leebron, Final Moments: Damages for Pain and Suffering Prior to Death, 64 N.Y.U. L. REV. 256, 259 (1989).

162. Air Transportation Safety and System Stabilization Act $\S 403$.

163. September 11 Victim Compensation Fund, Compensation for Deceased Victims; Distribution Plan Information (May 8, 2003), at http://www.usdoj.gov/victimcompensation/ distribution_plan.html.

164. Belkin, supra note 1 , at 92 .

165. See supra note 122 and accompanying text. 
I seriously doubt that he, the bill's namesake would have approved. ${ }^{166}$

Approximately 12,000 nonhemophiliacs contracted HIV from transfusions. ${ }^{167}$ In 2002, Congress considered an act to compensate non-hemophiliacs who contracted HIV from transfusions or their estates in line with the Ricky Ray Act, but bills in both houses seem to have stopped in committee. ${ }^{168}$ Interestgroup politics played a role in the disparity. Representatives of the National Hemophilia Foundation and other hemophilia advocacy groups initially argued that adding transfusion cases would have made the Ricky Ray Act too costly to pass. Today, they support efforts to compensate other transfusion victims. ${ }^{169}$ Such conflicts of interest may be present in any compensation scheme, and the tradeoff of political expediency (i.e., drawing sharp boundaries around the beneficiaries of a program) versus equity should be considered at the time of the program's creation.

\section{G. Practical Concerns with Legal and Ethical Implications}

Although the issues discussed above represent the most pressing legal and ethical questions in the design and implementation of a compensation program, other seemingly logistical concerns have moral elements. The first of these is the source of funds for compensation. If in a given program it is deemed appropriate for the federal government to provide compensation, how will those funds be allocated? In the NVICP, for example, compensation funds are limited. The Program allocated funds for injuries incurred before the enactment ${ }^{170}$ and established a trust fund for injuries incurred after. ${ }^{171}$ The trust is funded by a 75-cent tax on every covered vaccine sold in the United States. ${ }^{172}$ This vaccine-tax system represents a literal distribution of the costs of vaccine-related injuries over the population that receives childhood injuries (although, of course, many of these costs are covered for the population by insurers). This method of distributing the burden may not be available in every context.

Two related issues are the finiteness of the affected class and the implications for the viability of the program. Perhaps the most criticized example of a government compensation scheme is the black lung program,

166. NAT'L Ass'N OF Victims OF TRANSFUSION-ACQUIRED AIDS, INC., Steve Grissom Relief Fund Act, available at http://www.navta.org/advoc.htm (last visited Feb. 5, 2004).

167. See INST. OFMED., DIV. OF HEALTH PROMOTION \& DISEASE PREVENTION, supra note 121.

168. See H.R. 5299, 107th Cong. (2002); S. 2219, 107th Cong. (2002).

169. NAT'L ASS'N OF VICTIMS OF TRANSFUSION-ACQUIRED AIDS, INC., supra note 166.

170. 42 U.S.C. $\$ 300 \mathrm{aa}-15(\mathrm{j})(2003)$.

171. Id. § 300aa-15(i)(2); see also 26 U.S.C. $\$ 9510$.

172. U.S. GEN. ACCOUNTING OFFICE, supra note 144, at 7. 
which ballooned enormously from early estimates. ${ }^{173}$ At issue was not whether coal miners merited compensation, but rather the logic and coherency of the program itself:

The black lung program's arbitrary, unscientific use of presumptions vastly increased the compensation paid. This approach was 'the epitome of political manipulation of the pork barrel process under the guise of operating a workers' compensation scheme,' according to the most exhaustive study of the program to date. Kenneth Feinberg, perhaps the leading expert on the politics and administration of mass tort compensation programs, notes that Congress has taken one lesson away from its experience with the black lung program: 'Don't do it again.' 174

The harm in creating a program whose costs vastly outpace its estimated costs is, as the assessment above indicates, the hesitancy on the part of government to engage in any compensation programs at all. Furthermore, an unanticipated depletion of funds may prevent allocation of money to those most harmed.

A third logistical question, and the one with perhaps the clearest ethical implications, is that of the scope of compensation. Under tort law, different rationales underlie the various types of damages available. Lost earnings, for example, attempt to put the plaintiff in the position she would have held were it not for her injury. Punitive damages, in contrast, seek to express moral condemnation of the defendant's act or to create a deterrent effect against future harms. A compensation program can follow tort law in the state of each prospective recipient, or it can establish its own categories of appropriate compensation. These determinations, although at times highly technical, may have serious implications for equity, for the perception of the program, and for the program's viability and predictability.

\section{APPLYING THESE ISSUES TO A SMALLPOX COMPENSATION PROGRAM}

In this section, we offer a roadmap for how the above legal and ethical concerns might be addressed in the creation of a smallpox immunization compensation program.

173. Peter H. Schuck, Mass Torts: An Institutional Evolutionist Perspective, 80 CORNELL L. REV. 941 (1995).

174. Id. at 969 n.124. 


\section{A. Who Caused the Harm}

The question of whether the government is the actor causing the harm would depend upon the scenario. Of course, if a smallpox attack occurs, it will presumably not be a direct act of the American government. However, the immunization program itself will be, and the question of whether a government policy is the cause of any injuries or deaths that occur must be considered. For example, if the government urges citizens to be vaccinated in the absence of an actual attack, it might take on more responsibility for compensation than if an attack actually occurs. In the latter situation, the harm is arguably caused by the emergency brought about by the attack, rather than by our government.

\section{B. Foreseeability}

As discussed above, some harm is foreseeable in a mass smallpox immunization scheme. Rough estimates of the numbers of people affected by known side effects could be made. However, no mass smallpox immunizations have occurred in the age of HIV, chemotherapy, or immunosuppressive drugs. A compensation program would have to ask whether eligibility would only extend to those who experience entirely foreseeable (i.e. known) side effects, or also to those who manifest new responses to the vaccine. As the recent cardiac deaths illustrate, it may be difficult to establish if a certain illness or death is caused by the vaccine, which complicates the foreseeability analysis.

\section{Voluntariness}

The question of voluntary exposure to harm would be of utmost importance in creating this program. If the government mandated vaccination for any particular group (as it has for portions of the military), coverage of medical and other costs would be a clear moral imperative. However, rules must be established for situations in which people are vaccinated at different levels of voluntariness. Should the healthcare workers whom government wanted immunized be compensated because they were urged to get the vaccine, even though they volunteered? What about citizens who seek access to the unlicensed vaccine that the Administration plans to make available? If a smallpox attack actually occurs, are all vaccinations in the appropriate epidemiological area presumptively non-voluntary, or would such vaccinations in fact be formally mandated?

The presence of vulnerable subsets in the population complicates the issue of voluntariness. People with weakened immune systems or skin conditions, or those in close contact with them, may have to decide, in advance of a smallpox attack, if they want to be immunized. If people at higher risk of adverse reactions request vaccination despite being informed of their 
increased susceptibility to injury or death, should they have access to compensation funds? What if these same people are required to accept immunization in the event of an actual smallpox attack?

\section{Causation}

Issues of causation surrounding smallpox vaccination may be complex or simple, depending on the epidemiological scenario. If many people are vaccinated at the same time, it may be difficult to determine whether any resultant injuries were caused by vaccination of the plaintiff or by exposure to others who were vaccinated. Because any vaccinia reactions would be from the same mass immunization program, one possibility is not to make any inquiry into the source of infection, but simply to compensate all people who are injured by the vaccine. Because the vaccine contains vaccinia and not smallpox virus, there would be no difficulty in distinguishing vaccine effects from the effects of an actual attack, assuming appropriate laboratory facilities are available.

\section{E. Attempt to Avert a Greater Harm}

In the smallpox context, this issue arises most saliently when a smallpox attack has actually occurred. In this scenario, rapid immunization of large groups of people may be necessary in order to mitigate the spread of an epidemic. Screening of vulnerable subsets may not be feasible or desirable. Would the government's establishment of a compensation scheme be required in this case, if the harms that occur through immunizations are justified by the need to save large numbers of people? On an individual scale, are any harms incurred outweighed by the individual's own benefit of not contracting smallpox itself?

\section{F. Equity}

If a smallpox attack does occur, should those harmed by the vaccine be compensated while those who contract smallpox itself are not? Should people harmed indirectly be compensated? What subgroups of the population might be less likely to seek and receive compensation (consider undocumented immigrants), and how might this inequity be addressed?

\section{G. Awards: Funding, Finiteness, and Calculations:}

Where would the funds for a smallpox vaccine injury compensation program come from, and would benefits be capped? Would the economic costs of a program be predictable at the outset? If not, could the funds from which awards are made be somehow tied to the number of vaccines administered (e.g., through a tax)? Finally, how should benefits be calculated? 
Should compensation include just death benefits and medical expenses, or also future earnings and other economic loss?

\section{CONCLUSION}

The questions asked above are intentionally left unanswered. In the context of any national tragedy or government attempt to avert or mitigate such a tragedy, they should be asked, and answered through a thoughtful and transparent process. This should happen not just in the sphere of bioterrorism, but for any harm that affects Americans on a large scale. The ethical imperative is not to answer the questions in a certain way, but to ask them at all, and to do so before rushing into a potentially risky program. 
